\title{
FIFTH WORLD CONFERENCE ON EARTHQUAKE ENGINEERING
}

\author{
ROME, 25 - 29 JUNE, 1973
}

Report by R. Shepherd

Certainly in quantitative terms the Fifth World Conference on Earthquake Engineering held in Rome last June surpassed any of the four previous gatherings. Some nine hundred participants from forty-two countries had the opportunity of sampling more than four hundred papers presented in four concurrent ses'sions over eight half days. The largest national groups comprised more than two hundred registrants from each of Italy and the United States of America and approximately one hundred and fifty from Japan. Eight engineers travelled from New Zealand to attend the conference.

The venue, the Palazzo dei Congressi situated $6 \mathrm{~km}$ south of the city centre, proved ideal. All the lecture theatres, the reception hall, the refreshment areas and the ancillary offices were in the one building which forms one of the largest congress centres in Europe. Simultaneous translation facilities were available between English, French, German, and Italian for both the main invited lectures and the individual paper presentations.

Undoubtedly one of the objectives of the International Assocatiation, namely the stimulation of interest in Earthquake Engineering in the country chosen as venue for the conference, was achieved. The gathering together of such a large number of those engineers who have a special interest in the field also provided an excellent opportunity for the exchange of information so it was somewhat disappointing that this seemed to be more successfully undertaken outside the formal sessions of the conference rather than within them.

The pre-conference preparations had been so successful that apart from late registrants, and those of us from such distant places as New zealand, most of those attending did receive preprints of the papers some weeks before the conference. This prompted the organisers to allow only those discussions to be recorded which had been submitted in writing in advance of the presentation of the papers. This restriction, coupled with the ten minute time limit set for each paper presentation, effectively inhibited significant discussion within the formal sessions and hence detracted from the overall value of the conference.

It was evident that there had been virtually no spectacular developments in the earthquake engineering field since the last world conference. However, the steady dispersion of the understanding of established principles and techniques over the last four years resulted in their application to many specific problems being reported in Rome. Exceptions to this general trend could be found in the papers describing experimental testing of prototypescale structures, notably in Japan and California where recently completed large scale test facilities open up exciting prospects. On reflection, it appears inevitable that a stage is reached in the growth of any specific branch of engineering at which consolidation rather than spectacular innovative activity predominates. Such is the present situation in earthquake engineering in which incremental advances along a wide front have replaced drastic breakthroughs as the mode of development.

Apart from affording an opportunity to exchange views and news on the problems arising from earthquakes, Rome proved to be a fascinating place for engineers to visit. One can only wonder at the structural engineering achievements which have survived the decline and fall of a great empire to serve as a permanent reminder of one aspect of that greatness. The organising committee arranged several thoroughly appreciated social events. Two of these, involving visits to the Campidoglio and the Castel S. Angelo respectively, enabled the informal business of the conference to be combined with inspections of some of Rome's historic treasures.

The following officers of the International Association for Earthquake Engineering were elected by the National Delegates at the 5WCEE, to serve until the next International Conference which will be held in India, possibly at New Delhi, sometime between October 1977 and February 1978:

President:

E. Rosenblueth

(Mexico)

Executive Vice President: J. Ferry Borges (Portugal) Vice President: Jai Krishna (India)

Secretary General:

$\mathrm{J}$. K. Minami (Japan)

Directors:

N.N. Ambrayse

(U.K.)

A. Arias

G. Brankov

S. Cherry

L. Esteva

O.A. Glogau

G. Grandoni

D. E. Hudson

A. A. Monifar

S.V. Polibkov

H. Unemura

(Chile)

(Bulgaria)

(Canada)

(Mexico)

(N.Z.)

(Italy)

(U.S.A.)

(Iran)

(U.S.S.R.)

(Japan)

Additionally, Dr. G.W. Housner, immediate PastPresident, was elected an Honorary Member of the Association.

A list of the papers presented at the conference is given below. The Conference Proceedings, including all the technical papers and recorded discussions, are to be published in two hard cover volumes of approximately 1500 pages and may be obtained, at a cost of 30,000 Eire, plus 8,000 Lire for postage (i.e. for approx. $\$ N 250$ in total) from EDIGRAF - Editrice Libraria, Via Giuseppe Chiarini 6, 00137, Rome, Italy. 


\section{FIFTH WORLD CONFERENCE ON EARTHQUAKE ENGINEERING LIST OF PAPERS}

\section{Ses sion $1 A$}

\section{RECENT DESTRUCTIVE EARTHQUAKES}

1. The Major Papua New Guinea Earthquakes Near Madang (1970) and Beneath the North Solomon Sea (1971), by I.B. Everinghom, New Guinea.

2. Results of Engineering-Seismological Studies of the Zanghezour Earthquakes in 1968, by A.G. Nazarov, B.K. Karapetian, N.K. Karapetian, V.L. Mnatsakanian, S.A. Pirouzian, D.N. Roustanovich, S.A. Shahinian, and L.V. Shahsouvarian, U.S.S.R.

3. The San Fernando, California, Earthquake of February 9, 1971, by P.C. Jennings and G.W. Housner, California, U.S.A.

4. Response of the Olive View Medical Center Main Building During the San Fernando Earthquake, by A.K. Chopra, V.V. Bertero, and S.A. Mahin, California, U.S.A.

5. Evaluation of Olive View Hospital Behaviour on Earthquake Resistant Design, by L.G. Selna, M.D. Cho, and R.K. Ramanathan, California, U.S.A.

6. Design Implications of Damage Observed in the Olive View Medical Center Buildings, by V.V. Bertero, B. Bresler, L.G. Selna, A.K. Chopra, and A.V. Koretsky, California, U.S.A.

7. Performance of Underground Structures at the Joseph Jensen Filtration Plant, by L.A. Wylzie, jr., F.E. McClure, and H.J. Degenkolb, Califormia, U.S.A.

8. Earthquake Behaviour of Commercial-Industrial Buildings in the San Fernando Valley, by L.W. Bockemohle, California, U.S.A.

9. Engineering Lessons Taught by Earthquakes, by G.V. Berg and R.D. Hanson, Michigan, U.S.A.

9-a. Effects of Liquefaction at the Jensen Filtration Plant During the 1971 San Fernando Earthquake, by I.M. Idriss, L.S. Cluff, and M.S. Power, Califormia, $U . S . A$.

Session 1B

\section{RESPONSE OF STRUCTURES TO GROUND SHAKING}

10. On the Seismic Analysis of Unsymmetrical Storied Buildings, by E. Keintzel, Romania.

11. Identification of Damping Coefficients from System Response, by $P$. Caravani and W.T. Thomson, California, U.S.A.

12. Earthquake Response Prediction of Reinforced Concrete Buildings, by $M$. ozaki, Y. Ishiyama, and Y. Yamazaki, Japan. 
13. Prediction of the Torsional Response of a Multi-Story Reinforced Concrete Masonry Building by a Three Dimensional Dynamic Analyses, by G. Krishnamoorthy, G.A. Young, and G.A. Hegemier, California, U.S.A.

14. Determination of Composite Damping Matrices, by $J$. Pajuhesh and A.H. Hadjian, Califormia, U.S.A.

15. Dynamic Response of a Reinforced Concrete Structure with "Tied" and "Spiral" Columns, by H. Aoyama, Japan, and M.A. Sozen, IZZinois, USA.

16. Calculation of Building Response to Real Earthquake Accelerograms, by V.T. Rasskazovsky, U.S.S.R.

17. Torsional Analysis of Core wall structures, by W.K. Tso and J.K. Biswas, Canada.

18. Analysis of Torsional Oscillations, by P. Mazilu, H. Sandi, and D. Teodorescu, Romania.

19. On the Response Analysis of the Structure System Subjected to Multi-Seismic Motions, by H. Sato and K. Suzuki, Japan.

20. A Finite Element for the Interaction of Frames and Shear walls, by P. Ruiz and $F$. Reyes, Chile,

21. Earthquake Effects on Steel Tower Structures Atop Building, by T. Konno and E. Kimura, Japan.

22. Dynamic Instability and Ultimate Capacity of Parametrically Excited Structures, by F.Y. Cheng, W.H. Tseng, and J.H. Senne, Missoum, U.S.A.

22-a. Response Analysis of Frame Buildings with Filling Masonry at Non-elastic Deformations, by S. Sachanski, G. Brankov, and H. Nedialkov, Bulgaria.

Session $1 C$

\section{DYNAMIC TESTS OF STRUCTURES}

23. Vibration Tests on a Simple water Tower, by W.H. Boyce, New Guinea.

24. Vibration Tests on North Fork Dam Model, by J.P. Balsara and J. FowZer, Mississippi, U.S.A.

25. Providing an Earthquake-Like Environment for Testing Full-Scale Structures by Using the Ground Motion from Underground Nuclear Tests, by D.L. Bernreuter and F.J. Tokarz, California, U.S.A.

26. Dynamic Properties of Fourteen Story R.C. Frame Building from Full Scale Forced Vibration Study and Formulation of Mathematical Model, by $J$. Petrovski, D. Jumkovski, and T. Paskalov, Yugoslavia.

27. Researches on the Ductility of Reinforced Expanded Clay Concrete Members, by A. Negoita and I. Pop, Romania. 
28. Hysteretic Behaviour of Reinforced Concrete Rectangular and T-Beams, by H. Krawinkler and E.P. Popov, California, U.S.A.

29. Energy Dissipation in Strong Earthquake Motion of Existing Buildings, by K. Kanai, Japan (paper withdrawn from the author).

30. Ambient and Forced Vibration Studies of a Multistory Pyramid-Shaped Building, by J.G. Bouwkamp and R.M. Stephen, California, U.S.A.

31. Natural Periods of a Tall Shear wall Building, by G.T. Taoka, A.S. Furumoto, and A.N.L. Chiu, Hawaii, U.S.A.

32. Dynamic Response Study of the Palace Corvin Building in Caracas, Venezuela, by F. Briceno E., Venezuela, A.F. Espinosa, Colorado, U.S.A., and J. Arcia R., Venezuela.

33. The Ambient Vibration Survey, by I.R. Stubbs and V.R. McLamore, California, U.S.A.

34. Identification of Dynamic Structural Parameters from Experimental Data, by $P$. Ibanez and R.D. Sharman, California, U.S.A.

35. Investigation of the Dynamic Characteristics of the Offshore Oil-Field Structures, by I.P. Kuliev, G.A. Aliyev, and F.M. Gadjiev, U.S.S.R.

35-a. Experimental Studies of Dynamic Characteristics of Multy-Storey Steel Frame Building Large-Scale Models with Different Vertical Bracings, by V.N. Shaishmelashvili and N.A. Edisherashvili, U.S.S.R.

35-b. Earthquake Simulator study of a Reinforced Concrete Building Frame, by R.W. Clough and P. Hidalgo, Califormia, U.S.A.

35-c. Earthquake Simulator Study of a Three Story Steel Frame, by R.W. Clough and D. Tang, Califomia, U.S.A.

35-d. Dynamic Tests Up to Failure on Multi-Story Large Panel Buildings, by G. Serbanescu and T. Zorapapel, Romania.

Session 1D

\section{DYNAMICS OF SOILS AND SOIL STRUCTURES}

36. Wave Propagation and Lumped Mass Analysis Techniques Applied to the Determination of the Response of Multiple Layered Systems to Sinusoidal and Seismic Excitation, by J.H. Travers and R. Shepherd, New Zealand.

37. On the Characteristics of Seismic Motion on Soft Soil Layers, by A. Asada, $F$. Kawakami, and M. Kami yama, Japan.

38. Sand Liquefaction Under Random Earthquake Loading Condition, by $K$. Ishihara and S. Yasuda, Japan.

39. Consideration of Earthquake Resistant (Class I) Slopes and Dams, by T.S. Coughlin, D.E. Troxell, and P.C. Rizzo, Pennsylvania, U.S.A. 
40. Anti-Earthquake Measures for Embankment on a Weak Ground, by $H$. Uezawa and M. Nasu, Japan.

41. Shear Moduli of Soils, In-Situ and From Laboratory Tests, by K.H. Stokoe, II, Massachusetts, U.S.A., and F.E. Richart, Jr., Michigan, U.S.A.

42. Dynamic Analysis of Plane Non-Linear Earth Structures, by W.D.L. Finn and R.I.S. Miller, Canada.

43. Incorporation of Uncertainties in the Seismic Response of Soils, by J.E. Valera and N.C. Donovan, California, U.S.A.

44. Liquefaction Analysis of Saturated Granular Soils, by $J$. Ghaboussi and E.L. Wilson, Califomia, U.S.A.

44-a. A Study on Dynamics of Earth Dams During Earthquakes, by T.S. Atrakhova, G.N. Belgorodskaya, A.P. Valov, V.L. Golubyatnikov, M.M. Nikiforova, G.S. Seleznev, G.I. Tschalkina, and U.L. Zaslawskiy, U.S.S.R.

44-b. The Inverse Problem of Engineering Seismology, by S.G. Napetvaridze, A.R. Khvoles, and T.P. Vekua, U.S.S.R.

44-c. Analysis of the Seismic Response of Earth and Rockfill Dams, by J. Damy, L. Esteva, and V. Porras, Mexico.

44-d. Probabilistic Analysis of Nonlinear Seismic Response of Stratified Soil Deposits, by E. Faccioli and L. Esteva, Mexico.

44-e. Estimation of Seismic Stability of Earth Dams, by B.I. Didoukh, M.N. Bessonov, and S.I. KZjuchinkova, U.S.S.R.

44-f. On the Scattering Damping of Seismic Waves in a Random Soil Medium,by T. Kobori, Japan.

Session 2

Invited Lecture in the Main Hall of the Palazzo dei Congressi: Prof. K. Muto: Aseismic Design of Nuclear Power Plants.

\section{Session $2 A$}

\section{RECENT DESTRUCTIVE EARTHQUAKES}

45. Destructive Earthquake of 10 April 1972 in Ghir (Iran), by A.A. Moinfar, Iran.

46. An Engineering Study of the QIR Earthquake in Southern Iran, April 10, 1972, by R. Razani, Iran, and K.L. Lee, California, U.S.A.

47. Investigations on the Peruvian Earthquake of May 31, 1970, by J. Kuroiwa, E. Deza, and H. Jaen, Peru. 
48. Structural Behaviour in the 1970 Peru Earthquake, by G.V. Berg, Michigan, U.S.A., and R.L. Husid, Chile.

49. Engineering Aspects of the July 8, 1971 Earthquake in Central Chile, by R.M. Lastrico and $J$. Monge, Chile.

50. Damage on Low-Income Housing Due to the Earthquake of July 8th, 1971 in Chile, by $A$. Vives, V. Caruz, and H. San Martin, Chile.

51. The Luzon Earthquakes of August 2, 1968 and April 7, 1970, by A.R. Flores, Philippines.

52. Macroseismic Studies of Some Recent Indian Earthquakes, by S.K. Guha, P.D. Gosavi, and S.C. Marwadi, India.

53. Strong and Destructive Earthquakes and Seismic Activity of the Azerbaijan SSR and the Caspian water Area, by E.B. Agalarova, R.A. Agamirzoyev, E.K. Gyul, V.A. Kasparov, and F.T. KuZiyev, U.S.S.R.

54. Consequences of Tashkent Earthquake 1966 and Testing of Restored Brick walls, by T. Rashidov, V.T. Rasskazovsky, and K.S. Abdurashidov, U.S.S.R.

55. Observations on the Behaviour of Reinforced Concrete Framed Buildings During 22 May 1971 Bingol Earthquake, by E. Karaesmen, Turkey.

56. Railway Embankments in the 1968 Tokachioki Earthquake, by Y. Kobayashi and T. Fujiwara, Japan.

57. The Structural Performance of the Rural Dwellings During Recent Destructive Earthquakes in Turkey (1969-1972), by E. Arioglu and K. Anadol, Turkey.

58. Reasons for the Earthquake Damage to the New High School Building in Burdur, Turkey, by S.S. Tezcan, M. Ipek, and S. Acar, Turkey.

Session 2B

\section{RESPONSE OF STRUCTURES TO GROUND SHAKING}

59. Behaviours of Submerged Tunnels During Earthquakes, by S. Okamoto, C. Tamura, K. Kato, and M. Hamada, Japan.

60. Seismic Design Spectra for Trans-Alaska Pipeline, by N.M. Neumark and W.J. HaZl, IZZinois, U.S.A.

61. Spectra for Earthquake Resistive Design of Underground Long Structures, by Y. Aoki and S. Hayashi, Japan.

62. Behaviour of Underground Waterpipes During an Earthquake, by K. Kubo, Japan.

63. On the Earthquake Response of Submerged Tunnels, by Y. Goto, J. Ota, and T. Sato, Japan.

64. Vibration Test of the Underground Pipe with a Comparatively Large CrossSection, by N. Nasu, S. Kazama, T. Morioka, and T. Tamura, Japan. 
65. The Principles of the Dynamic Theory of Earthquake Resistance of the Complex Systems of Underground Structures, by T. Rashidov, U.S.S.R.

66. A Proposal for Earthquake Response Analyses of Long Structures and Aseismic Design Criteria of Pipe Lines, by A. Sakurai, C. Kurihara, and $T$. Takahashi, Japan.

67. An Assessment of the Earthquake Resistant Design of Electrical Power Transmission Facilities, by M.S. Agbabian, Califormia, U.S.A., and C.C. Diemond, Oregon, U.S.A.

68. Use of Nonlinear Analysis to Interpret Earthquake Response of Pendular Supported High Voltage Electrical Equipment, by K.L. Merz, S.A. Adhom, and P.J. Richter, Califormia, U.S.A.

69. Earthquake Analysis and Specification of the High Voltage Electrical Equipment, by $F$. Novoa M., Chile.

70. Seismic Effects in Flexible Liquid Storage Tanks, by A.S. Veletsos, Texas, U.S.A.

71. The Seismic Response of Elevated Water Tanks Supported on Cross Braced Towers, by $R$. Shepherd, New Zealand.

72. Seismic Analysis of Liquid Sodium Storage Tanks, by C.J. Costantino and C.A. Milzer, New York, U.S.A.

72-a. Overview of Earthquake Protection of Telecommunications Facilities in Buildings, by J.W. Foss, New Jersey, U.S.A.

\section{Session $2 C$}

\section{SEISMICITY AND GROUND MOTIONS}

73. Observation and Analysis of Underground Earthquake Motions, by T. Tanaka, S. Yoshizawa, T. Morishita, K. Osada, and Y. Osawa, Japan.

74. Effects of Seismic and Subsoil Conditions on Earthquake Response Spectra, by E. Kuribayashi, T. Iwasaki, Y. Iida, and K. Tuji, Japan.

75. Characteristics of Seismic Waves in Bedrock at the Higashi-Matsuyama Earthquake, by K. Seo, N. Konoue, T. Tsunoda, S. Watanabe, and K. Nakagawa, Japan.

76. Strong Motion During Earthquakes, by W.K. Cloud, California, U.S.A.

77. Spectral Analysis of Site Effects in the San Fernando Earthquake, by C.M. Duke and P.J. Hradilek, California, U.S.A.

78. Local Distribution of Strong Earthquake Ground Motions, by D.E. Hudson and F.E. Udwadia, California, U.S.A.

79. Characterization of Response Spectra by Parameters Governing the Gross Nature of Earthquake Source Mechanisms, by M.D. Trifunac, California, U.S.A.

80. Earthquake Ground Motion Near the Source, by A.K. Mal and A.R. Carriveau, california, U.S.A. 
81. Characteristics of Base Rock Motions Calculated from Strong Motion Accelerograms, by H. Tsuchida, T. Uwabe, and S. Hayashi, Japan.

82. Some Problems in Determining Earthquake Ground Motions on Base Rock, by K. Irikura, J. Akamatsu, and T. Fumizawa, Japan.

83. Comments on Earthquake Transmission from Basement Rock to Surface, by W.J. Hall, N.M. Newmark, and B. Mohraz, IZZinois, U.S.A.

84. Ground Amplification Studies in the Caracas Valley and the Northern Coastal Area of Venezuela, by A.F. Espinosa and S.T. AZgermissen, Colorado, U.S.A.

85. Inference of Underground Seismic Motions from Surface Accelerograph Records, by K. Toki, Japan, and S. Cherry, Canada.

86. Amplification Studies of the Pacoima Dam from Aftershocks of the San Fernando Earthquake, by W.V. Mickey, Colorado, U.S.A., V. Perez, and W.K. Cloud, Califormia, U.S.A.

87. Microtremor Studies in Adapazari, Turkey, by S.S. Tezcan, Turkey.

87-a. Caracas Earthquake of July 1967 - Geophysical Field Measurements, by D. Linehan and V.J. Murphy, Massachusetts, U.S.A.

Session $2 D$

\section{DYNAMIC BEHAVIOUR OF STRUCTURAL ELEMENTS}

88. Behaviour of Reinforced Concrete External Beam-Column Joints Under Cyclic Loading, by R. Park and T. Paulay, New Zealand.

89. Experimental Study of Spandrel Wall Assemblies, by J.G. Bouwkamp and O. Kustu, California, U.S.A.

90. Shear Explosion of Reinforced Concrete Short Columns, by M. Yomada and S. Yagi, Japan.

91. Inelastic Lateral Buckling of Steel Beams Subjected to Repeated and Reversed Loadings, by K. Takanashi, Japan.

92. Hybrid Failure Test on a Structural Member, by M. Hakuno, Japan.

93. Spirally Reinforced Concrete Columns Subjected to Loading Reversals Simulating Earthquake Effects, by B.I. Karlsson, Sweden, H. Aoyama, Japan, and M.A. Sozen, IIZinois, U.S.A.

94. Shear Failure of Reinforced Concrete Columns Subjected to Cyclic Loading, by J.K. Wight, IZZinois, U.S.A., and Y. Konoh, Japan.

95. Dynamic Characteristics of Reinforced Concrete Beam-Column Specimens for Various Levels of Cracking, by R.M. McCafferty and M.L. Moody, Colorado, U.S.A.

96. Experimental Study on Large Models of Reinforced Concrete Columns, by $M$. Hirosawa, M. Ozaki, and M. Wakabayashi, Japan. 
97. The Influence of the Elastic Plastic Deformation of Beam-to-Column Connections on the Stiffness, Ductility and Strength of Open Frames, by B. Kato and M. Nakao, Japan.

98. On the Rigidity and Ductility of Steel Bracing Assemblage, by R. Tanabashi, $K$. Kaneta, and T. Ishida, Japan.

99. An Empirical Evaluation of Inelastic Behaviour of Structural Elements in Reinforced Concrete Frames Subjected to Lateral Forces, by S. Sugano and I. Koreishi, Japan.

100. Elastic-Plastic Behaviour of Steel Braces Under Repeated Axial Loading, by M. Shibata, T. Nakomura, N. Yoshida, S. Morino, T. Nonaka, and M. Wakabayashi, Japan.

101. Seismic Interaction Between Parts of a Dynamic System, by W.D.L. Finn, Canada, and $E$. Varoglu, Turkey.

101-a. Behaviour of Masonry Walls Under Lateral Loads, by R. Meli, Mexico.

Session $3 A$

\section{DESIGN AND REPAIR OF STRUCTURES}

102. Fundamental New Aseismic Design of Reinforced Concrete Buildings, by M. Yamada and $H$. Kawomura, Japan.

103. An Example of Epoxy Mortar Repair of a Reinforced Concrete Beam-Column Joint, by R.M. McCafferty and M.L. Moody, Colorado, U.S.A.

104. An Investigation of the Design and Repair of Low-Rise Shear Walls, by F. Barda, J.M. Hanson, and W.G. Corley, IZZinois, U.S.A.

105. Restoration of Earthquake Damaged Concrete and Masonry, by $J$. Warner, California, U.S.A.

106. Repair of Buildings Damaged by the 1969 Boland Earthquake, by C.J. Thompson, South Africa.

107. Design Lessons Learned from the Performance of Instrumented High-Rise Buildings in the San Fernando Earthquake, by W.E. Gates, California, U.S.A.

108. Evaluation of Earthquake Resistant Properties and Strengthening of Existing Building, by T. Miki, T. Homma, and M. Hirosawa, Japan.

109. Strength, Stiffness and Ductility Properties of Slender Shear Walls, by E.A.B. Salse and M. Fintel, Illinois, U.S.A.

110. Earthquake Resistant Design of Reinforced Concrete Structures with External Short Columns and Deep Spandrel Beams, by R. Razani, Iran, and J.G. Bouwkamp, California, U.S.A.

111. Design of Earthquake-Resistant Structural Walls, by W.G. Corley and J.M. Hanson, IZZinois, U.S.A.

111-a. Earthquake-Repair-Earthquake, by H. Gallegos, R. Rios, C. Casaborme, $C$, Uccelli, and G. Icochea, Peru. 
Session 3B

\section{RESPONSE OF STRUCTURES TO GROUND SHAKING}

112. Dynamic Properties of Highway Bridges, by E. Kuribayashi and T. Iwasaki, Japan.

113. Seismic Response of Highway Overcrossings, by W.S. Tseng and J. Penzien, Califomia, U.S.A.

114. Dynamic Response of Arches Under Seismic Forces, by S.K. Thakkar and A.S. Arya, India.

115. (Withdrawn and inserted in session $6 \mathrm{~A}$ under same number).

116. Stress-Strain Analysis Method for Dams Under Seismic Actions, by L.I. Dyat lovitsky and V.P. Turov, U.S.S.R.

117. A Finite Element-Analogue Method for Determining the Dynamic Characteristics of an Arch Dam-Reservoir System, by B. Nath, England.

118. Earthquake Behaviour of Arch Dam-Reservoir Systems, by P.R. Perumalswami and L. Kar, South Dakota, U.S.A.

119. An Arch Dam Design Method for Seismic Loadings, by G.C. Rouse and L.H. Roerm, Colorado, U.S.A.

120. Earth Dam Motion Due to a Deep Nuclear Explosion, by L.W. Heller, Mississippi, U.S.A., and J.E. Ahlberg, Georgia, U.S.A.

121. Foundation-Dam Interaction and Spatial Variation in Ground Motion, by M.J. Kaldjian, Michigan, U.S.A.

122. Analysis of Non-Elastic and Non-Linear Vibration of Rock Fill Dams Using Finite Element Method, by $H$. Watanabe, Japan.

122-a. Seismic Response of Van Norman Reservoir Outlet Towers, by S.A. Gadmoski, Califormia, U.S.A.

122-b. Periods of Vibration of a Nuclear Power Facility, by H. Giuliani, H.J. Cano, and J.S. Carmona, Argentina.

122-c. Seismic Analysis of Arch Dams, by T. Hatano and T. Nakagawa, Japan.

122-d. Aseismic Design of Arch Dams with Account of Section and Block Joints Opening and Closing, by V.N. Lombardo, U.S.S.R.

122-e. The Selection of Seismic Design Loadings by the Use of Return Period Graphs, by J.P. Hollings, New Zealand.

Session 3C

\section{EARTHQUAKE INSTRUMENTATION}

123. Present-Day Status of Worldwide Strong-Motion Instruments, by C.F. Knudson, California, U.S.A. 
124. Studies on a Network of Strong Motion Accelerographs to be Installed in Italy, by E. Iaccarino and C. Zaffiro, Italy.

125. Deployment of Strong Motion Seismographs in Western Canada, by W.G. Milne and G.C. Rogers, Canada.

126. A Technical Review of Recent Strong Motion Accelerographs, by H.T. Halverson, Califomia, U.S.A.

127. Soviet Instruments for Registration of Strong Earthquakes, by E.S. Borisevich, D.P. Kimos, and V.M. Fremd, U.S.S.R.

128. Multi-Pendulum Seismometers of New Design, by B.K. Karapetian, A.S. Mouradian, A.K. Mouradian, and A.G. Nazarov, U.S.S.R.

129. Magnetic Tape Recording and Processing of Strong-Motion Data, by W.J. Rihn, California, U.S.A.

130. Strong Motion Observation System with a wide Amplitude Range. Part I: Construction of Headquarters Station, by Y. Ohta and T. Asada, Japan.

131. Structural Monitoring Techniques and Instrumentation for Nuclear Power Plants, by P.S. Klasky, R.R. Staton, I.R. Stubbs, and J.E. Fix, Texas, U.S.A.

132. A Plan for Strong Earthquake Alarm System 10 Seconds Before it Attacks the City of Tokyo, by Earthquake Alarm Group (K. Kanai, S. Okamoto, H. Kobayashi, M. Katsumata, M. Hakuno, and Y. Ohta, Japan).

133. The Problems of Engineering Seismometric Service Organization and Instrumental Data Analysis, by S.V. Poliakov, B.E. Denisov, B.A. Kirikov, O.I. Ponomarev, G.V. Momaeva, and Y.A. Vypryazhkin, U.S.S.R.

133-a. A Strong Motion Radio Telemetry Network, by J. Prince, H. Rodriguez, E.Z. Jaworski, and G. Kilander, Mexico.

Session 3D

\section{DYNAMIC BEHAVIOUR OF STRUCTURAL ELEMENTS}

134. Prismatic Reinforced Concrete Members Alternate Bending Beyond the Yielding of the Reinforcement under Axial Loads, by $A$. Parducci and $A$. Samuelzi Ferretti, Italy.

135. Cyclic Load Tests on Shear wall Panels, by C.M. Alexander, A.C. Heidebrecht, and W.K. Tso, Canada.

136. Shear Walls - Research and Design Practice, by A.E. Cardenas E., Peru.

137. Hysteresis Loops for Reinforced Concrete Beam-Column Connections, by W. $H$. Tounsend and R.D. Hanson, Michigan, U.S.A.

138. A Study on Reinforced Concrete Slitted Shear Walls for High-Rise Buildings, by K. Muto, N. Ohmori, and T. Takahashi, Japan. 
139. Strength Degradation of Reinforced Concrete Columns Subjected to MultiCycle Reversals of Lateral Load at Given Amplitudes of Post-Yielding Deformation, by T. Shimazu and M. Hirai, Japan.

140. Elasto-Plastic Behaviour of Reinforced Concrete Beams with Spandrel Walls Under Anti-Symmetric Cyclic Loads, by Y. Higashi, M. Ohkubo, and K. Iida, Japan.

141. Experimental Study on Low Cycle Fatigue of a Structural Member Subjected to Earthquake Loads, by Y. Gyoten, K. Mizuhata, and I. Tsuyama, Japan.

142. Experimental Study on Dynamic Properties of Reinforced Concrete Shear Walls, by T. Shiga, A. Shibata, and J. Takahashi, Japan.

143. Vibration Test of Steel Frame Having Precast Concrete Panels ,by N. Uchida, T. Aoyagi, M. Kawomura, and K. Nakagawa, Japan.

144. Cyclic Loading on Externally Reinforced Masonry Walls, by W.K. Tso, E. Poliner, and A.C. Heidebrecht, Canada.

145. Cyclic Behaviour of Rolled Steel Members, by W.P. Vann, Texas, U.S.A., L.E. Thompson, Missouri, U.S.A., L.E. WhalZey, Texas, U.S.A., and L.D. Ozier, Georgia, U.S.A.

146. Inelastic Behaviour of Steel Frames Subjected to Constant Vertical and Alternating Horizontal Loads, by M. Wakabayashi, C. Matsui, K. Minami, and I. Mitani, Japan.

147. Factors Influencing the Hinging Behaviour of Reinforced Concrete Members Under Cyclic Overloads, by J.O. Jirsa, Texas, U.S.A.

148. Experimental Research on the Elastoplastic Behaviour in Dynamic Operative Conditions of Systems of Two Degrees of Freedom, by G.M. Bo, A. Castoldi, L. Goffi, Italy, and A. Popovici, Romania.

\section{Session 4}

Invited Lecture in the Main Hall of the Palazzo dei Congressi: Prof. N.N. Ambraseys: Dynamics of Soils and Soil-Structure Interaction

\section{Session $4 A$}

\section{EARTHQUAKE GROUND MOTIONS}

149. Research Activity on Design Response Spectra for Italian Sites, by $A$. Castellani and V. Petrini, Italy.

150. Recent Developments in Data Processing and Accuracy Evaluations of Strong Motion Acceleration Measurements, by M.D. Trifunac, F.E. Udwadia, and A.G. Brady, Califormia, U.S.A.

151. Statistical Characteristics of Response Spectra of Earthquake Motions in Japan, by M. Hirasawa, T. Suzuki, and T. Kuwabara, Japan. 
152. Peak Ground Accelerations and Their Effect on the Velocity Response Envelope Spectrum as a Function of Time, San Fernando Earthquake, February 9, 1971, bu V. Perez, Califomia, U.S.A.

153. Spectral Analysis of the July 8, 1971 Earthquake in Central Chile, by $R$. Husid, Chile, and C. Medone, Argentina.

154. Standard Data Processing of Strong Motion Accelerograms, by A.G. Brady and D.E. Hudson, California, U.S.A.

155. A Statistical Evaluation of Strong Motion Data Including the February 9, 1971 San Fernando Earthquake, by N.C. Donovan, California, U.S.A.

156. Time Variation of Ground Motion Frequency Content: Characterization and Relevance, by G.R. Saragoni, Chile, and G.C. Hart, Califormia, U.S.A.

157. Earthquake Response Analysis and Data Processing by the Fourier Transform, by T. Itoh, H. Yomahara, and Y. Otsuki, Japan.

158. Determination of Isoacceleration Lines by Sliding and Overturning of Objects, by J. Krishna, A.S. Arya, and K. Kumar, India.

159. Computation of Individual Fourier Spectrum Ordinates, by P.C. Jennings, Califormia, U.S.A.

160. Theoretical Simulation of Earthquake Acceleration Spectra, by D. Ozgur and A. Gurpinar, Turkey.

160-a. On the Strong Motion Accelerograms Obtained in Japan, by M. Watabe, K. Ishida, K. Nakagawa, Y. Oscawa, H. Murata, S. Omote, T. Tanaka, Y. Kitagawa, and Y. Ohsaki, Japan.

160-b. A Comparison of the Spectra of Moderate and Small Earthquakes, by $D$. Tocher, California, U.S.A.

160-c. Some Considerations from Strong Motion Instrumental Data Obtained During Ancona Seismic Period of 1972, by C. Zaffiro et a., Italy.

292. Duration of strong Ground Motion, by B.A. Bolt, California, U.S.A.

\section{Session 4B}

\section{RESPONSE OF STRUCTURES TO GROUND SHAKING}

161. Influence of Bridge Bearings on Aseismic Design of Simply Supported Bridge Spans, by J. Krishna and A.R. Chandrasekaran, India.

162. Studies on the Earthquake-Resistant Design of Suspension Bridge Tower and Pier System, by Y. Yamada, Y. Goto, and H. Takemiya, Japan.

163. Non-Linear Response and Structural Ductility of Reinforced Concrete Buildings Under Strong Seismic Actions, by A. Ravara and R.T. Duarte, Portugal.

164. Inelastic Seismic Behaviour of Frame-Wall Systems, by R.K. Wen, Michigan, U.S.A., and P.S. Natarajan, India. 
165. Inelastic Dynamic Analysis of a 60 story Building, by J. Lord, C. Meyer, $J$. Brent Hoerner, and M. Zayed, California, U.S.A.

166. Simplified Analysis of Shear Walls in Tall Buildings to Earthquake Action, by $M$. Ifrim and $A$. Dobrescu, Romania.

167. Analysis of Multi-Story Bearing Wall Structures, by A. Bratescu, M. Ionita, H. Sandi, and I. Simulescu, Romania.

168. Seismic Response of Buildings With and without Basements and Piles, by J.K. Minami and J. Sakurai, Japan.

169. The Influence of the Behaviour of the Material on Response of the Structures to Dynamic Loads, by L. Munziante, Italy.

170. Earthquake Response of Reinforced Concrete Structures Considering the Discontinuous Failure Process to Collapse, by S. Tani, S. Nomura, T. Nagasaka, A. Hiramatsu, and I. Mochizuki, Japan.

171. Response Analysis of Reinforced Concrete Structures Under Seismic Forces, by H. Miguruma, M. Tominaga, and F. Watanabe, Japan.

172. Effective Live Load Under Earthquake Conditions in Multi-Story Frames, by $A . R$. Chandrasekaran, India.

173. A New Type Shock Absorber and its Effects on the Response of the Bridge to the Earthquake, by T. Kitta, J. Kodera, K. Ujiie, and H. Tada, Japan.

174. Seismic Response of Reticular Elasto-Plastic Structures, by A. La Tegola and G. Sara, Italy.

Session $4 C$

\section{DYNAMIC TESTS OF STRUCTURES}

175. A New Measuring Method of Vibration Using Correlation Technique, by $K$. Auto, T. Ohta, K. Uchida, N. Adachi, and Y. Kasai, Japan.

176. A New Seismic Frequency Range Shaker for Modal Testing of Large Structures, by F.M. Tillou and K.J. Metzgar, California, U.S.A.

177. Effects of Test Specimen Reaction Loads on Shaking Tables, by Y. Takahashi, D. Rea, and S. Abedi-Hayati, Califormia, U.S.A.

178. Ambient Vibration Tests on Full-Scale Structures, by F.E. Udwadia and M.D. Trifunac, California, U.S.A.

179. High-Rise Building Response: Damping and Period Nonlinearities, by G.C. Hart, M. Lew, and R. Di Julio, Jr., Califormia, U.S.A.

180. Dynamic Response of a $20 \mathrm{Ft} . \times 20 \mathrm{Ft}$. Shaking TAble, by D. Rea and.J. Penzien, Califormia, U.S.A.

181. Dynamic Collapse Tests of Steel Structural Models, by B. Kato, H. Akiyama, H. Suzuki, and Y. Fukazawa, Japan. 
182. Rate of Loading Effects on Uncracked and Repaired Reinforced Concrete Members, by V.V. Bertero, D. Rea, S. Mahin, and M.B. Atalay, Califormia, U.S.A.

183. Response of a Bridge and Its Subsoil to Ground Shaking, by T. Fujiwara and $J$. Kawamata, Japan.

184. Moment-Resisting Steel Subassemblages Under Seismic Loadings, by E.P. Popov, V.V. Bertero, and H. Krawinkler, Califormia, U.S.A.

185. Response of Reinforced Masonry Shear Walls to Static and Dynamic Cyclic Loading, by D. Willioms, Califormia, U.S.A., and J.C. Scrivener, New Zealand.

186. Structural Response to Man-Induced Ground Motion, by J.A. Blume and S.A. Freeman, California, U.S.A.

187. Substitute Damping Ratios for Reinforced Concrete Frames in the PostYield Range, by $P$. Gulkan, Turkey.

188. Dynamic Response of Framed Structures With Infill Walls, by R.V. Dawson and M.A. Ward, Canada.

188-a. Photoelastic Analysis of Models Subjected to Earthquake Simulation, by F. Focardi, Italy.

Session 4D

\section{DYNAMICS OF SOILS AND SOIL STRUCTURES}

189. Three Dimensional Dynamic Response and Earthquake Resistant Design of Rock Fill Dam Against Input Earthquake in Direction of Dam Axis, by $M$. Hayashi, H. Komada, and Y. Fujiwara, Japan.

190. Variation in Soil Properties During Dynamic Loading, by M.A. Sherif and M.J. Wh, Washington, U.S.A.

191. Vibration of the Ground, Especially of the Superficial Soil Layers, by K. Kotota and T. Morioka, Japan.

192. Earthquake Induced Cracking of Dry Canyon Dam, by K.L. Lee and H.G. Walters, Califormia, U.S.A.

193. On the Response Calculation in the Time Domain of the Ground Considered the Viscosity and the Energy Dissipation to the Bedrock Layer, by $Y$. Yomazaki, Japan.

194. Calculation of Residual Slope Deformations and Saturation Effect in Aseismic Analysis of Earth Structures, by A.N. Birbrayer, L.A. Eisler, and A.I. Smiltnec, U.S.S.R.

195. Dynamic Earth Pressures on Basement Wall, by H. Tajimi, Japan.

196. Dynamic Behaviour of Rockfill and Earth Dams Studied on Elastic Models, by $G$. Oberti, A. Castoldi, and M. Casirati, Italy. 
197. Some Dynamic Behaviours of Undisturbed Cohesive Soils from Laboratory Tests, by A. Enami and M. Ohhashi, Japan.

198. Longitudinal Waves Propagation in Specimens of Incoherent Soils and Discontinued Materials, by $A$. Capecchi and G. Conti, Italy.

199. The Three Dimensional Stress, Strain and Damping Response of a Cyclically Stressed Sand-Clay, by B. Shackel, Australia.

200. Dynamic Tests of Soil Embankments, by S. Noda, H. Tsuchida, and E. Kurata, Japan.

201. Dynamic Behaviour of Weak Soils Treated with Additives, by Y.S. Chae, New Jersey, U.S.A., and Y.C. Chiang, Formosa.

202. Earthquake Induced Earth Pressures on Retaining Walls, by R.F. Scott, Califormia, U.S.A.

202-a. A New Material for Dynamic Tests of Rockfill Dam Models, by J. Diaz and o. Rascon, Mexico.

\section{Session 5}

Invited Lecture in the Main Hall of the Palazzo dei Congressi: Prof. E. Rosenblueth: Analysis of Risk

\section{Session $5 \mathrm{~A}$}

\section{EARTHQUAKE GROUND MOTIONS AND ZONING}

203. Problems in Seismic Zoning, by G.W. Housner and P.C. Jennings, Califormia, U.S.A.

204. A Local Seismic Intensity Zoning Map Based on Subsoil Conditions, by $H$. Kobayashi and H. Kagami, Japan.

205. Seismic Zoning of Continental Shields, by L.S. Srivastava, India.

206. Seismic Risk in South America to the South of 20 Degrees, by J.S. Carmona and J.C. Castano, Argentina.

207. Ground Motions as a Function of Seismicity, by J.L. Justo and B. Bayan, Spain.

208. Earthquake Intensity and Smoothed Earthquake spectra, by A. Arias S., Chile.

209. Ground Motions in the Epicentral Area of Earthquakes, by S.K. Guha, S.P. Agarwal, K. Nand, and P.D. Gosavi, India.

210. Recency of Faulting: A Widely Applicable Criterion for Assessing the Activity of Faults, by J.I. Ziony, C.M. Wentworth, and J.M. Buchanan, California, U.S.A.

211. A Model for Predicting Seismic Intensity, by J.F. Evernden, R.R. Hibbard, and J.F. Schneider, Virginia, U.S.A. 
212. Considerations on Earthquake Force Evaluation, by S. Omote and K. Yoshimura, Japan.

213. Destructive Power of Earthquakes, by $J$. Ibanez, Chile.

214. Earthquake Hazard in the Caribbean Area on the Basis of Historical Studies, by J.P. Grases, Venezuela.

215. Some Results of the Investigations in the Seismic Microzoning of Banjaluka, by M. Stojkovic and V. Mihailov, Yugoslavia.

215-a. Introduction to the Seismic Risk in Italy, by M. Caputo, Italy.

215-a.bis Proposals for a More Thorough Evaluation of the Seismic Risk in Italy, by V. Perinetti, F. Della Scala, S. Crescenzi, and M. Caputo, Italy.

215-b. Seismicity of Slovenia and a Portion of Croatia, by V. Ribaric, Yugoslavia, and S.T. Algermissen, Colorado, U.S.A.

215-c. Seismic Potential in the Western Nevada/Eastern California Region, by A. Ryall, W.U. Savage, and C.J. Koizumi, Nevada, U.S.A.

Session 5B

\section{RESPONSE OF STRUCTURES TO GROUND SHAKING}

216. Consideration of Effect of Hysteresis Damping for Composite Systems, by $F$. Horie and T. Odaka, Japan.

217. Inelastic Structures with Set-Backs, by O.A. Pekau and R. Green, Canada.

218. Ductility Requirements for Some Nonlinear Systems Subjected to Earthquakes, by E.A. Anagnostopoulos and J.M. Roesset, Massachusetts, U.S.A.

219. Earthquake Analysis of Steel Frames with Non-Rigid Joints, by J. Vasquez, Chile, E.P. Popov, and V.V. Bertero, California, U.S.A.

220. Effect of Degrading Stiffness on the Response of Multistory Frames Subjected to Earthquakes, by F.A. Imbeault, Canada, and N.N. Nielsen, Hawai U.S.A.

221. Earthquake Response of Frame Structures Composed of Inelastic Members, by T. Kobori, R. Minai, and T. Fujiwara, Japan.

222. A Model for the Dynamic Analysis of Deteriorating Structures, by W.D. Iwan, California, U.S.A.

223. Calculated Inelastic Structural Response to Uniaxial and Biaxial Earthquake Motions, by D.A.W. Pecknold and M.A. Sozen, IZZinois, U.S.A.

224. Linear and Nonlinear Earthquake Analysis of Complex Structures, by K.J. Bathe and E.L. Wilson, California, U.S.A.

225. A Comparison of Linear and Exact Nonlinear Analyses of Soil Amplification, by I.V. Constantopoulos, J.M. Roesset, and J.T. Christian, Massachusetts, $U . S . A$. 
226. Cumulative Damage Effects in Seismic Structures, by W.A. Nash and U.T. Chon, Massachasetts, U.S.A.

227. Non-Linear Dynamic Analysis of Buildings with Torsional Effects, by S.A. Anagnostopoulos, J.M. Roesset, and J.M. Biggs, Massachasetts, U.S.A.

228. Response Spectral Solution for Structures with Multiple Support Input, by C.W. Lin, Pennsylvania, U.S.A.

228-a. Earthquake Response of Ramberg-Osgood Systems with Gravity Effects, by $J$. Solnes, Iceland, and $R$. Sigbjornsson, Denmark.

Session $5 C$

\section{FOUNDATIONS AND SOIL-STRUCTURE INTERACTION}

229. The Dynamic Response of Pile Foundations to Lateral Forces, by I. Alpan, Israel.

230. Earthquake Response of Multi-Story Building Considered Surface LayerBasement Interaction, by T. Masao and H. Tajimi, Japan.

231. A Fast Fourier Transform Approach to Earthquake Soil-Structure Interaction Problems, by S.C. Liu and L.W. FageZ, New Jersey, U.S.A.

232. Damping Coefficients of Structural Vibration Related to Subsoil Conditions, by $H$. Kobayashi, Japan.

233. Soil-Structure Interaction of Massive Embedded Structures During Earthquakes, by H.B. Seed and I.M. Idriss, California, U.S.A.

234. Response Analyses of Earthquake Motions Observed in and Around a Reinforced Concrete Building Including Building-Subsoil System, by Y. Osawa, Y. Kitagawa, and $K$. Ishida, Japan.

235. Soil-Structure Interaction of Dynamically Laterally Loaded Pile Based on Discrete-Element Method, by S.L. Agarwal, India.

236. Dynamics of Elastic and Yielding Structure-Foundation Systems, by A.S. Veletsos, Texas, U.S.A., and B. Verbic, Yugosiavia.

237. Investigation of Soil Building Interaction System on Large Models With Precast Panel, by $Y$. Kitagawa, R. Tomura, Y. Tonaka, and $Y$. Osawa, Japan.

238. Coupled Response of Two Foundations, by P.B. MacCalden and R.B. Matthiesen, California, U.S.A.

239. An Experimental Study on Structure-Ground Interaction, by M. Shinozuka, New York, U.S.A., and T. Fukuda and H. Asada, Japan.

240. The Effect of Plane Shape and Size of Buildings on the Input Earthquake Motions, by S. Tani, J. Sakurai, and M. Iguchi, Japan.

241. Interaction Between a Large Structure and the Ground, by Y. Ohchi, Japan.

241-a. Seismic Soil-Structure Interaction of Embedded Buildings, by R.A. Parmelee and R.J. Kudder, IZZinois, U.S.A. 
Session 5D

\section{EARTHQUAKE-RESI STANT DES IGN}

242. Earthquake Resistant Design of a 20 Story Reinforced Concrete Building, by K. Muto, T. Hisada, T. Tsugawa, and S. Bessho, Japan.

243. New Zealand Parliament Buildings: Beehive, by O.A. Glogau, A.J. Ballintine, R.L. Williams, and h.E. Chapman, New Zealand.

244. Earthquake Design of a 32-Story A-Shape Reinforced Concrete Building, by A. Mazzeo La Creta, Venezuela.

245. Earthquake Resistant Design of 52-Storied Shinjuku-Sumitomo Building, by K. Yano, H. Suitsu, and H. Kobayashi, Japan.

246. Seismic Studies of Parque Central Buildings, by M. Paparoni, Venzuela, J. Ferry Borges, A. Ravara, Portugal, and R.V. Whitman, Massachusetts, U.S.A.

247. Design of Shear Wall Systems for Non-Elastic Behaviour During a Major Earthquake, by T. Zsutty, Califormia, U.S.A.

248. Some Seismic Aspects of Coupled Shear Walls, by T. Paulay, New Zealand.

249. Preliminary Seismic Analysis of Reinforced Concrete Tall Buildings, by T. Guendelman and $J$. Monge, Chile.

250. Design of Ductile Flat Plate Structures to Resist Earthquakes, by J.E. Carpenter, P.H. Kaar, and W.G. Corley, Illinois, U.S.A.

251. Aseismic Analysis of the Tall Building Structure with Coupled Shear Wall, by T. Hisatoku and H. Matono, Japan.

252. An Energy Dissipation Factor as Structural Design Criterion for Strong Earthquake Motion, by J. Gluck, Israel.

253. Damping in Nuclear Reactors, by G.C. Hart, R.B. Matthiesen, P. Ibanez, C.B. Smith, R. Vasudevan, and R. Di Julio, Jr., Califomia, U.S.A.

253-a. Seismic Analysis of Lightweight Elastic Systems in Nuclear Power Plants, by Z.D. Jankov and C.F. Reeves, Massachusetts, U.S.A.

253-b. Earthquake Design of Refinery Structures, by R.A. Flores and H.C. del Rosenfeld, Chile.

\section{Session $6 \mathrm{~A}$}

\section{FOUNDATIONS AND SOIL-STRUCTURE INTERACTION}

254. Determination of Foundation Flexibilities of structure, by J.H. Rainer, Canada.

255. The Dynamic Behaviour of Structures as Influenced by Soil-Structure Interaction, by A.J. Carr and P.J. Moss, New Zealand.

256. Dynamical Interaction of Multiple Structural Systems on a soil Medium, by $T$. Kobori and $R$. Minai, Japan. 
257. Vibrations of Under Ground Structure or of Revised Ground Portion Due to Earthquake and Those Influences to the Surrounding Ground, by T. Tajime and $K$. Miura, Japan.

258. Evidence of Soil-Structure Interaction in Earthquakes, by P.J. Hradilek, A.R. Carriveau, California, U.S.A., G.R. Saragoni, Chile, and C.M. Duke, California, U.S.A.

259. Elastic-Plastic Earthquake Response of Soil-Building Systems, by T. Minami, Japan.

260. Dynamic Response of Buildings Supported on Piles Extending Through Soft Alluvial Subsoil Layers, by $T$. Ohta, A. Hara, S. Uchiyama, and M. Niwa, Japan.

261. A Study of the Reaction of Structures Under Seismic Effects and the Mutual Effect of Structures with the Ground of the Base, by A.G. Nazarov, R.O. Amassian, S.S. Darbinian, B.K. Karapetian, N.K. Karapetian, and S.S. Simonian, U.S.S.R.

262. Seismic Response of Structures Buried Partially in a Multi-Layered Soil Medium, by T. ABe and A.H.-S. Ang, IZZinois, U.S.A.

263. Soil-Structure Interaction Effects in the Caracas Earthquake of 1967, by H.B. Seed, Califormia, U.S.A., and J.L. Alonso, Venezuela.

264. Dynamic Analysis of Ground-Structure System, Based on Elastic Wave Theory, by H. Tsutsumi, Y. Kamiya, T. Kudoh, and S. Taguchi, Japan.

265. A Comparative Study Between Theory and Observation on Soil-Structure Interaction Problem, by I. Sakamoto and M. Izumi, Japan.

265-a. Dynamic Response of Embedded Foundation, by J. Petrovski, Yugoslavia.

265-b. Soil-Structure Interaction Effects on the Earthquake Response of Chimneys, by J.E. Luco, Chile.

115. Dynamic Analysis of Structure-Foundation Systems, by A.K. Vaish and A.K. Chopra, California, U.S.A.

Session 6B

\section{RESPONSE OF STRUCTURES TO GROUND SHAKING}

266. Earthquake Response of Single-Degree-of-Freedom Hysteretic Structures, by H. Goto, Japan, and H. Iemura, Califormia, U.S.A.

267. Response of Reinforced Concrete Structures Characterized by "Skeleton Curve" and "Normalized Characteristic Loop" to Ground Motions, by S. Tani and S. Nomura, Japan.

268. Gravity Effect on the Catastrophic Dynamic Response of Strain-Hardening Multi-Story Frames, by R. Tanabashi, T. Nakamura, and S. Ishida, Japan.

269. Effect of Gravity Loading on the Earthquake Response of Cooling Towers, by V.I. Weingarten, S.F. Masri, M. Lashkari, and K. Kahyai, Califormia, U.S.A. 
270. Restoring Force Characteristics of Steel Diagonal Bracings, by S. Igarashi, K. Inoue, M. Asano, and K. Ogawa, Japan.

271. Inelastic Earthquake Response of Reinforced Concrete Buildings, by $K$. Yoshioka, T. Takeda, and K. Nakagawa, Japan.

272. General Purpose Computer Program for Inelastic Dynamic Response of Plane Structures, by G.H. Powell, and A. Kanaan, Califormia, U.S.A.

273. Reliability of a Randomly Excited Ductile Reinforced Concrete Frame, by A. Gurpinar and E. Karaesmen, Turkey,

274. Some Effects of Nearby Structures on the Seismic Response of Buildings, by J. Sakurai and J.K. Minami, Japan.

275. Analysis of the Behaviour of Reinforced Concrete Structures During Strong Earthquakes Based on Empirical Estimation of Inelastic Restoring Force Characteristics of Members, by H. Umemura, H. Aoyama, and H. Takizawa, Japan.

276. Earthquake Response of a Building Collided with a Neighbouring Building, by K. Takeyama, Japan.

277. Inelastic and Reserve Energy Analysis of Multistoreyed Buildings, by A.S. Arya, India.

278. Influence of the nonelastic Deformations on the Structures on the Changing of Dynamic Characteristics and Response, by S. Sachansky and G. Brankov, Bulgaria.

279. Statistical Analysis of Nonlinear Parametric Systems by Strong-Motion Earthquake Excitation, by N.A. Nikolaenko and S.V. ULjanov, U.S.S.R.

Session 6C

\section{EARTHQUAKE-RESISTANT DESIGN}

280. Earthquake Resistant Design of Bridges and the N.Z. Ministry of Works Bridge Design Manual, by H.E. Chapman, New Zealand.

281. Codes and Engineering Practices as Related to Current Research Developments, by H.J. Degenkolb, California, U.S.A.

282. Elements of a Dynamic-Inelastic Design Code, by J.A. Blume, Califormia, U.S.A.

283. A Rational Approach to Seismic Design Standards for Structures, by N.M. Newmark and W.J. Hall, IZlinois, U.S.A.

284. New Design Standards for Hydraulic Structures in the Seismic Zones of the U.S.S.R., by O.A. Savinov, S.G. Napetvaridze, N.D. Krasnikov, V.F. Ivanistchev, and J.I. Natarius, U.S.S.R.

285. Earthquake-Resistant Design of Structures Having Brittle-Type Load Resisting Elements with Emphasis on Masonry and Adobe Buildings in Iran, by R. Razini, Iran.

286. Force Deflection-Ratio, Its Control and Design, by R. Flores A. and $R$. Arias, F., Chize. 
287. Aseismic Design Procedure for Staggered Truss Framed Buildings, by R.D. Hanson and G.V. Berg, Michigan, U.S.A.

288. Parabolic Lateral Loads for Earthquake Resistant Structures, by G. Estrada-Uribe, Colombia.

289. On the Earthquake Resistance of the Suleymaniye Mosque (Istanbul), in the Historical Perspective (1557-1973), by E. Arioglu and K. Anadol, Turkey.

290. Aseismic Design of Buildings with the Ground Frame Storey, by F.V. Bobrov, E.E. Zukov, L.S. Kilimnik, G.S.Kulygin, E.S. Medvedeva, and V.S. Pavlyk, U.S.S.R.

290-a. Method of Determining Earthquake Resistante of Residential Buildings on the Basis of Vibrational Tests by Means of High-Power Generators, by G.A. Shapiro and V.F. Zakharov, U.S.S.R.

290-b. Earthquake Resistance of Prestressed Reinforced Concrete and Conventional Precast Structures, by T.Z. Zhanusov, U.S.S.R.

Session 6D

\section{SEISMICITY AND GROUND MOTIONS}

291. Some Strong-Motion Results from Papua New Guinea 1967-1972 , by D. Denham, G.R. Small, Australia, and I.B. Everingham, New Guinea.

292. (Relazione inserita, con lo stesso numero, nella sessione 4A).

293. Evaluation of the Pacoima Dam Accelerogram, by R.B. Reimer, R.W. Clough, and J.M. Raphael, Califormia, U.S.A.

294. Interpretation of Apparent Upthrow of objects in Earthquakes, by $N_{.} M$. Newmark, IIZinois, U.S.A.

295. Dynamic Analysis of Strike-slip Faulting, by J.D. Achenbach, IZlinois, U.S.A., and A.M. Abo-Zena, Califoria, U.S.A.

296. Dynamic Properties of an Earthquake Source, by P.G. Richards, New York, U.S.A.

297. Influence of Fluid Injection on Stress in the Earth's Crust, by P.A. Witherspoon and Y.N.T. Maini, California, U.S.A.

298. Behaviour of S-Waves in Soft Ground, by T. Terashima, Japan.

299. Deformation of the Van Norman Reservoirs Area, Northern San Fernando Valley, California, by R.F. Yerkes, T.L. Youd, and J.N. Alt, California, U.S.A.

300. Parameters of Stress Waves Produced by a Spherical Explosive Source, by V. Schenk, Caechoslovakia.

301. A Deterministic Near-Field Source Model, by J.H. Dieterich, Califormia, U.S.A.

301-a. Empirical and Theoretical Study of Near-Fault wave Propagation, by D.M. Boore, California, U.S.A.

301-b. Earthquakes Associated with Water Reservoirs, by A. Garcia Yague, A. Lopez Arroyo, and F. Reig Vilaplana, Spain. 
Invited Lecture in the Main Hall of the Palazzo dei Congressi:

Prof. G.W. Housner: Important Features of Earthquake Ground Motion.

Session 7A

\section{ASEISMIC DESIGN OF NUCLEAR POWER FACILITIES}

302. Seismic and Geologic Siting Considerations for Nuclear Facilities, by H.W. Coulter, Washington D.C., U.S.A., H.H. Waldron, Colorado, U.S.A., and J.F. Devine, Maryzand, U.S.A.

303. Feasibility Studies for an Atomic Power Plant on Alluvial Soil in Seismic Zone, by J. Krishna, A.S. Arya, A.R. Chandrasekaran, B. Chandra, S.K. Thakkar, and $P$. Nandakumaron, India.

304. Seismic Considerations in Nuclear Power Plant Siting and Desing, by R.B. Matthiesen, G. Howard, and C.B. Smith, Califormia, U.S.A.

305. Selection of Seismic Design Parameters for a Nuclear Facility, by $J . A$. Fischer, H. Singh, and J.G. McWhorter, New York, U.S.A.

306. Survey of Aseismic Design Data for Nuclear Power Plants, by D.S. Mehta, P.T. Kuo, and A.A. Vizzi, Maryland, U.S.A.

307. On Design Criteria for Equipment Mounted on a Massive Structure, by $A$. Castellani, Italy.

308. Experience with Current USAEC Criteria for Seismic and Geologic Investigation, by P.C. Rizzo and S.D. Wermer, Pennsylvania, U.S.A.

309. Seismic Analysis of the Primary Building of a BW Reactor, by L. Lazzeri and T. Sano, Italy.

310. Seismic Analysis of Nuclear Components Considering Modeling Uncertainties, by S.W. Tagart, Jr. and M.R. Torres, California, U.S.A.

311. Determination of Subsurface Ground Stresses from a Given Surficial Design Response Spectra, by D.E. Shaw and S.J. Jarecki, Pennsylvania, US.A.

312. Rocking Effects in a Nuclear Power Plant Subjected to a Seismic Disturbance by C.A. Milzer and C.J. Costantino, New York, U.S.A.

313. Seismic Fatigue Considerations in Nuclear Power Plant Design, by P.G. Smith, Florida, U.S.A.

314. Seismic Design of Small Diameter Pipe and Tubing for Nuclear Power Plants, by J.D. Stevenson, PennsyZvania, U.S.A.

315. Seismic Shear Transfer Across Cracks in Concrete Nuclear Reactor Containment Vessels, by R.N. White, P. Gergely, J.P. Laible, and O.A. Fajardo, New York, U.S.A.

316. Earthquake Engineering in France, by C.E. Plichon, France,

316-a. Experimental Research on the Aseismic Strength of Shielding Blocks in the Fast Breeder Reactor, by $M$. Watabe, Japan. 
Session 7B

\section{STATIST ICS AND ASSESSMENT OF SEISMIC RISK}

317. Quantification of Design Rules Based on the Assessment of Earthquake Risks, by d. Ferry Borges, Portugal.

318. Optimum Design with Equivalent Seismic Loads, by E. VitielZo, Italy.

319. Design Decisions for Seismic Structures, by I.H. Chou, New Jersey, U.S.A., J.E. Goldberg, and J.T.P. Yao, Indiana, U.S.A.

320. Methodology for Optimum Seismic Design, by E.H. Vanmarcke, C.A. CornelZ, R.V. Whitman, Massacharsetts, U.S.A., and J.W. Reed, Nevada, U.S.A.

321. Earthquake Damage Probability Matrices, by R.V. Whitman, Massachusetts, U.S.A., J.W. Reed, Nevada, U.S.A., and S.T. Hong, Massachusetts, U.S.A.

322. On the Choice of the Acceptable Seismic Risk - a New Approach, by $G$. Grandom and D. Benedetti, Italy.

323. A Stochastic Model for Predicting Seismic Response of Light Secondary Systems, by $A . K$. Singh and A.H.-S. Ang, Illinois, U.S.A.

324. Statistically Efficient and Computationally Efficient Identification of Structural Parameters from Random vibration Records, by $W$. Gersch, $N . N$. Nielsen, Hawaii, U.S.A., and H. Akaike, Japan.

325. Estimating structural Parameters from Response Data, by A.J. Schiff, P.J. Feil, and J.L. Bogdanoff, Indiana, U.S.A.

326. Aftershocks in Engineering Seismic Risk Analysis, by H.A. Merz and C.A. Corne ZI, Massachusetts, U.S.A.

327. Forecasting the Risk in Earthquake Resistant Design, by H.C. Shah and V.N. Vagliente, Califomia, U.S.A.

327-a. Reliability Optimization in Earthquake Engineering, by E. Rosenblueth, Mexico.

327-b. Comparative Studies on Methods of Seismic Load Prediction Applied to Iran, by M. Amin, A.A. Moinfar, and M. Banisadr, Iran.

327-c. Seismic Risk on Layered Nonlinear Soil, by L. Esteva and R. Cervantes, Mexico.

327-d. Computer Determination of Aggregate Expected Earthquake Loss Within a Specific Area, by H.F. Lewis and R.M. Lincoln, Massachusetts, U.S.A.

\section{Session $7 C$}

\section{FOUNDATIONS AND SOIL-STRUCTURE INTERACTION}

328. Vibrational Characteristics of the Structure Influenced by the Ground, by M. Takeuchi, K. Kotota, and S. Kazama, Japan.

329. A New Method of Evaluating Seismic stability of steel Pile structures, by S. Hayashi, Japan. 
330. Dynamic Coefficients for Evaluating the Seismic Response of Soil-Structure Interaction Systems, by R.A. Parmelee and J.H. Wronkiewicz, IZlinois, U.S.A.

331. Simple Medels for Foundations in Lateral and Rocking Motion, by J.W. Meek, West Germany, and A.S. Veletsos, Texas, U.S.A.

332. Effects of Soil Deposits on Seismic Behaviour of Prefabricated Highway Tunnels, by E. Kuribayashi and T. Iwasaki, Japan.

333. Retaining walls in Seismic Areas, by M.S. Aggour and C.B. Brown, Washington, U.S.A.

334. Evaluation of Dynamical Properties of Pile Foundation Based on Wave Dissipation Theory, by M. Häkuno, Japan.

335. Experimental Study on Vibrational Characteristics of the Structures with Embedded Foundation, by $K$. Kinoshita and $H$. Kushida, Japan.

336. Earthquake Response Analysis of Elastoplastic Structure-Ground Systems of Shear Type by the Direct Numerical Analysis Method, by Y. Gyoten, $K$. Mizuhata, Y. Fukuda, M. Kawamoto, and T. Shinomiya, Japan.

337. The Effect of Embedment on Vibration of Footings and Structures, by M. Novak, Canada.

338. Sway-Rocking Vibration of Rigid Structure Embedded in an Elastic Stratum, by Y. Yasui and K. Nakagawa, Japan.

339. Hysteretic Damping Systems Applied to Soil-Structure Interaction by Finite Element Method, by Y. Matsushima, Japan.

340. Soil-Structure Interaction in the May 31, 1970 Peruvian Earthquake, by F. Romani, Peru.

341. Investigation in Spring Coefficients for the Base of Foundation Made of Cross Continuous Beams, by D.D. Barkon, M.N. Golubtsova, and O. Ya. Sheckter, U.S.S.R.

Session 70

\section{DYNAMIC TESTS OF STRUCTURES}

342. Dynamic Properties and Earthquake Response of a 9 Story Reinforced Concrete Building, by T. Shiga, A. Shibata, and J. Shibuya, Japan.

343. Measurements and Statistical Evaluation of Dynamic Characteristics of FullScale structures, by H.C. Shah, C.A. Kircher, and A.E. Eskel, Califormia, U.S.A.

344. A System for Measuring Normal Modes of Structures, by W.R. Stephenson and R.I. Skinner, New Zealand.

345. Earthquake Resistance of a Steel Frame Apartment House with Precast Concrete Panel, by M. Murakami, R. Tomura, Y. Tanaka, K. Oami, Y. Osawa, and H. Umemura, Japan.

346. Vibration Test on the Longest Prestressed Concrete Bridge, by M. Mikoshiba, F. Nemoto, Y. Nojiri, and Y. Kasai, Japan. 
347. Response of Three-Story Reinforced Concrete Frames Subjected to Simulated Earthquake Motions, by S. Otani and M.A. Sozen, Illinois, U.S.A.

348. Seismic Response of a Great Panel Structure with Ten Stories, by D. Diacorar, M. Manolovici, C. Mihai, M. Iticovici, and D. Vasilescu, Romania.

349. Damage Prediction for Low-Rise Buildings, by J.A. Blume, Califormia, U.S.A., and R.E. Scholl, Nevada, U.S.A.

350. Experiment and Research on the Response of Steel Model Structures Subjected to Impact Horizontal Loading and to Simulated Earthquakes, by H. Okada, T. Takada, K. Yoshioka, Y. Omote, and K. Nakagawa, Japan.

350-a. Theoretical and Experimental Investigations of Precast and Monolithic Frameless Buildings on Large-Scale Reinforced Concrete Models, by Y.V. Barkov and Y.V. GZina, U.S.S.R.

350-b. Study of Non-Linear Work of Construction of Reinforced Precast Concrete and Monolithic Framework Building by Powerful Vibration Generators, by $Y_{\bullet} A$. Simon, V.F. Zakharov, G.N. Ashkinadze, and E.S. Gorlova, U.S.S.R.

\section{Session $8 A$}

\section{SPEC IAL PROBLEMS OF EARTHQUAKE ENGINEERING}

351. Effectiveness of the Tsunami Warning System in Selected Coastal Towns in Alaska, by J.E. Haas and P.B. Trainer, Colorado, U.S.A.

352. Tsunami Anomalies and Precursory Phenomena Having Potential Value as Predictors, by W.M. Adams, Hawaii, U.S.A.

353. Multi-Degree of Freedom Response Spectra for Elastic Systems, by E.J. Teal, J. Lord, and C. Meyer, Califormia, U.S.A.

354. Dynamic Behaviour of Tall Buildings with Cladding, by I.J. Oppenheim, Pennsyzvania, USA.

355. A Tentative Method for Recording and Analysing Seismic Darnages in one Story Dwellings, by E. Caleagni, A. Vives, V. Caruz, and H. San Martin, Chile.

356. Cumulative Damage of Plastic Frames Subjected to Earthquakes: A Probabilistic Approach, by G. Augusti and A. Baratta, Italy.

357. Experimental Studies of Earthquake Resistance of a System with Disengaging Ties, by S.V. Poliakov, J.M. Eisenberg, and V.K. Papelishili, U.S.S.R.

357-a. Cumulative Fatigue Damage in Seismic Structures, by M. Suidan, Lebonon, and R.A. Eubanks, ILlinois, U.S.A.

357-c. Structure of an Earthquake Proof Building with Heightened Energy-Consumption, by S.I. KLigerman and M.I. Medvedev, U.S.S.R.

357-d. Solutions and Economics of Rural Housing in Earthquake Areas of Iran, by S. Yaghmai and M. Amin, Iran.

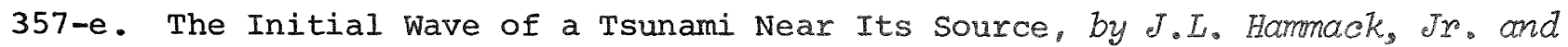
F. Raichlen, Califomia, U.S.A. 
Session 8B

\section{STATISTICS AND ASSESSMENT OF SEISMIC RISK}

358. Maximum Response Statistics for a Linear Structure, by L.D. Lutes and N.C. Chokshi, Texas, U.S.A.

359. Probabilistic Seismic Analysis of Light Equipment Within Buildings, by M.K. Chakravorty and E.H. Vanmarcke, Massacharsetts, U.S.A.

360. Digital Simulation of Ground Accelerations, by M. Shinozuka, New York, U.S.A.

361. Analysis and Design of Hysteretic Structures for Probabilistic Seismic Resistance, by D. Veneziano, Italy.

362. Probabilistic Seismic Response of Simple Inelastic Systems, by E.H. Vanmarcke and D. Veneziano, Massachusetts, U.S.A.

363. Probabilistic Assessment of Maximum Response Acceleration, by T. Katayama, Japan.

364. Analysis and Modeling of Earthquake Data, by F. Kozin and R. Gran, New York, U.S.A.

365. Stochastic Network Formulation and Solution of Earthquake Risk in Structural Design, by A.H. Peyrot and W.E. Saul, Wisconsin, U.S.A.

366. The Minimax, Versus the Statistical, Prediction of Earthquake Resistance, by R.F. Drenick, New York, U.S.A.

367. On Fluctuation of Responses of a Structure, by H. Shibata, N. Shimizu, M. Yomamuro and T. Shigeta, Japan.

367-a. On an Earthquake Simulation Model, by O.A. Rascon and M. Chavez, Mexioo.

Session $8 \mathrm{C}$

\section{RESPONSE OF STRUCTURES TO GROUND SHAKING}

368. Earthquake Response of Multi-Story Building Supported on Piles, by $S$. Yamomoto and T. Seki, Japan.

369. Effects of Gravity Loads and Vertical Ground Acceleration on the Seismic Response of Multistory Frames, by J.C. Anderson and V.V. Bertero, California, U.S.A.

370. Energy Absorption Devices for Earthquake Resistant Structures, by R.I. Skinner, J.M. Kelly, and A.J. Heine, New Zealand.

371. Seismic Behaviour of Multistory Braced Steel Frames, by C. Goel and R.D. Hanson, Michigan, U.S.A.

372. Earthquake Response Spectra of Systems Provided with Nonlinear Auxiliary Mass Dampers, by S.F. Masri and L.L. Yang, California, U.S.A.

373. Application of Input Controlling Mechanisms to Structural Design of a Tall Building, by K. Matsushita and M. Izumi, Japan. 
374. Structural Optimization in Aseismic Design, by N.C. Nigam and S. Narayanan, India.

375. Optimal Designing of Tower Structures Under Seismic Action, by G. Brankov and I. Paskaleva, Bulgaria.

376. Optimization of Framed Structures Under Earthquake Loads, by $J$. Solnes, Iceland, and O.L. Holst, Denmark.

Session 80

\section{DISASTER PREVENT ION}

377. Mitigating Earthquake Effects on Electric Power Systems, by A.J. Schiff and J.T.P. Yao, Indiana, U.S.A.

378. Efforts to Correct Existing Earthquake Hazardous Buildings in the State of California, by E.M. O'Connor, California, U.S.A.

379. Hazard Reduction Through Earthquake Resistant Design, by E.C. Brinley, Jr., Connecticut, U.S.A.

380. Implementation of California's Seismic Planning Law at the Local Government Level, by R.L. Meehan, California, U.S.A.

381. Earthquake Disaster Preparedness: Engineering Aspects of Planning, $b y$ K.V. Ste inbrugge and H.J. Lagorio, Califormia, U.S.A.

382. Earthquake Engineering for the Smaller Dwelling, by F.W. Evans, Missouri, U.S.A.

382-a. The Role of Engineering and Technical Schools in Seismic Disaster Prevention. The Chilean Case, by A. Echeverria and P. Gomez, Chile.

382-b. Theoretical Analysis of Expected Damages for the Given Earthquake Intensity, by M.G. Korf and K.M. Matvejev, U.S.S.R.

382-C. Earthquake Disaster in Managua, Nicaragua, by J.E. Haas, Colorado, U.S.A. 